\title{
An Oleic Acid-Mediated Pathway Induces Constitutive Defense Signaling and Enhanced Resistance to Multiple Pathogens in Soybean
}

\author{
Aardra Kachroo,, ${ }^{1}$ Da-Qi Fu, ${ }^{1}$ Wendy Havens, ${ }^{1}$ DuRoy Navarre, ${ }^{2}$ Pradeep Kachroo, ${ }^{1}$ and Said A. Ghabrial ${ }^{1}$ \\ ${ }^{1}$ Department of Plant Pathology, University of Kentucky, Lexington 40546, U.S.A.; ${ }^{2}$ Department of Plant Pathology, \\ United States Department of Agriculture-Agricultural Research Service, Washington State University, Prosser 99350, U.S.A.
}

Submitted 20 November 2007. Accepted 25 January 2008.

\begin{abstract}
Stearoyl-acyl carrier protein-desaturase (SACPD)-catalyzed synthesis of oleic acid (18:1) is an essential step in fatty acid biosynthesis. Arabidopsis mutants (ssi2) with reduced SACPD activity accumulate salicylic acid (SA) and exhibit enhanced resistance to multiple pathogens. We show that reduced levels of 18:1 induce similar defense-related phenotypes in soybean. A Bean pod mottle virus (BPMV)-based vector was employed to effectively silence soybean $S A C P D s$. The silenced plants contained reduced 18:1 and increased stearic acid, developed spontaneous cell death lesions, increased SA accumulation, and constitutively expressed pathogenesis-related genes. These plants also expressed elevated levels of resistance-like genes and showed resistance to bacterial and oomycete pathogens. Exogenous application of glycerol induced similar phenotypes, mimicking the effect of silencing $S A C P D s$ in healthy soybean plants. Overexpression of a soybean $S A C P D$ increased 18:1 levels in ssi2 but not in wild-type Arabidopsis plants, suggesting that the soybean enzyme was under feedback regulation similar to that of the Arabidopsis isozymes. These results suggest that soybean and Arabidopsis respond similarly to 18:1-derived cues by inducing a novel broad-spectrum resistance-conferring pathway, even though they differ significantly in their lipid biosynthetic pathways. We also demonstrate the efficacy of BPMV-induced gene silencing as a tool for functional studies in soybean.
\end{abstract}

Additional keywords: Phytophthora sojae, Pseudomonas syringae pv. glycinea, soybean defense.

Fatty acids (FAs) are important energy storage molecules that are critical for maintaining membrane integrity. In plants, FA biosynthesis occurs exclusively in the plastids and requires the activity of the soluble stearoyl-acyl carrier protein-desaturase (SACPD). This enzyme introduces a cis-double bond at the carbon position 9 of the saturated FA, stearic acid (18:0), to form the monounsaturated FA, oleic acid (18:1). SACPDs have been identified in a variety of plant genomes (Akagi et al. 1995; Nishida et al. 1992; Shanklin and Sommerville 1991; Slocombe et al. 1992; Taylor et al. 1992; Thompson et al. 1991), and several of these appear to encode for multiple isoforms (Byfield et al. 2006; Jain et al. 1999; Kachroo et al.

Corresponding author: Aardra Kachroo; E-mail: apkach2@uky.edu

* The $e$-Xtra logo stands for "electronic extra" and indicates that a supplemental figure and a supplemental table are published online.
2007). Although the specific functions of each isoform are not clear, studies on mammalian stearoyl desaturases suggest that different isoforms may participate in tissue- or substrate-specific activities (Zheng et al. 2001). Indeed, several plants encode for SACPD enzymes with altered substrate-length specificities (14:0 and 16:0) (Cahoon et al. 1994; Schultz et al. 1996) or insert double bonds at alternative positions $(\Delta 4$ and $\Delta 6$ ) (Cahoon et al. 1992, 1997a, 1998). Thus, the presence of multiple SACPD isoforms in an organism need not necessarily ensure compensatory or overlapping functions. For example, six other SACPD isozymes were unable to complement for the loss of activity in the Arabidopsis major isoform, SSI2 (Kachroo et al. 2001, 2007). Analyses of the enzymatic activities of the other leaf-expressed isoforms have revealed that their inability to compensate for loss of SSI2 functions could be attributed to the low specific activities of these enzymes (more than $90 \%<$ SSI2) (Kachroo et al. 2007).

Extensive structure-function analyses as well as sequence comparison studies of SACPD proteins have allowed the identification of the precise residues determining substrate specificity and site of double-bond placement (Cahoon et al. 1998; Lindqvist et al. 1996). Site-directed mutagenesis of these residues has facilitated the redesigning of $S A C P D$ s to produce proteins with modified, agriculturally important activities (Cahoon et al. 1997b). Because SACPD introduces the first degree of desaturation in the FA moiety, manipulating the activity of this enzyme can alter the ratio of unsaturated to saturated FAs. In mammalian systems, changes in the ratio of saturated to unsaturated FA, resulting from alterations in stearoyl desaturase activity, is associated with a variety of physiological disorders, including diabetes, obesity, neurological disease, and cancer (Ntambi and Miyazaki 2003). In plants, such changes are known to affect membrane fluidity (Wade and Bishop 1978). Thus, SACPD activity also participates in maintaining membrane integrity and fluidity, and likely functions in membrane stabilization during cold acclimatization (Grillo et al. 1998; Vannini et al. 2004). Indeed, enzymatic analysis of proteins from developing soybean seed showed that reduced growth temperatures increased SACPD activities (Cheesbrough 1990). In addition to abiotic stress, SACPDs also participate in plant responses to biotic stress (Kachroo et al. 2001; Pegadaraju et al. 2005).

We previously have shown that reduced SACPD activity induces altered defense signaling in Arabidopsis (ChandraShekara et al. 2007; Kachroo et al. 2001, 2003a,b, 2004, 2005). A mutation in the Arabidopsis SSI2 gene results in constitutive upregulation of salicylic acid (SA)-mediated defense responses. The mutant plants are stunted in size and exhibit cell death le- 
sions on their leaves. Furthermore, the ssi2 plants also accumulate high levels of SA and overexpress pathogenesis-related $(P R)$ genes. Consequently, these plants exhibit enhanced resistance to bacterial and oomycete pathogens (Kachroo et al. 2001; Shah et al. 2001). Characterization of ssi2 suppressor mutants showed that the altered defense-related phenotypes resulted from a reduction in 18:1 levels. Restoring wild-type (WT) levels of 18:1 via genetic mutations in the glycerol-3-phosphate (G3P)-acyl transferase $(A C T 1)$ or the G3P dehydrogenase $(G L Y 1)$ gene are able to restore all the altered phenotypes in ssi2 plants (Kachroo et al. 2003, 2004). Moreover, exogenous application of glycerol reduces the endogenous 18:1 levels (likely by increasing G3P levels) and mimics ssi2-like phenotypes in WT plants (Kachroo et al. 2004, 2005). More recently, we showed that the low 18:1 in ssi2 plants resulted in increased expression of a variety of resistance $(R)$ genes (Chandra-Shekara et al. 2007).

Two genes encoding SACPD proteins have been identified in soybean (Byfield et al. 2006). The encoded proteins designated $G m S A C P D-A$ and $-B$ are over $98 \%$ identical. Analysis of transcript levels using primers specific for a variable region has shown that the expression levels of GmSACPD-A and $G m S A C P D-B$ are nearly similar in nonseed tissues but show slight differences during various stages of seed development. We employed a reverse genetics approach to characterize the soybean $S A C P D$ genes and examine their defense-related functionalities. The GmSACPD-A or $G m S A C P D-B$ as well as a third gene, GmSACPD-C, were silenced using our recently developed, novel, Bean pod mottle virus (BPMV)-based vector. This BPMV-based vector can be used effectively to silence endogenous sequences as well as overexpress heterologous genes in soybean (Zhang and Ghabrial 2006). BPMV has a bipartite positive-strand RNA genome consisting of separately encapsidated RNA1 and RNA2. BPMV RNA1 codes for five mature proteins required for replication whereas RNA2 codes for a putative cell-to-cell movement protein (MP) and the two coat proteins (L-CP and S-CP). A stable BPMV-based vector was generated by inserting target sequences into the RNA2encoded polyprotein open reading frame, between the MP and L-CP coding regions, and constructing additional proteinase cleavage sites to flank the foreign protein (Zhang and Ghabrial 2006).

Here, we present data demonstrating that loss of $S A C P D$ induces a variety of defense-related phenotypes and confers resistance to multiple pathogens in soybean. Our results indicate that a low 18:1-mediated defense signaling pathway is highly conserved in diverse plants like Arabidopsis and soybean.

\section{RESULTS}

\section{Sequence conservation among the soybean $S A C P D$ isoforms.}

$\mathrm{SACPD}$ is the only enzyme responsible for the formation of the essential monounsaturated FA, 18:1, in plants, and several plant species have multiple isoforms of this enzyme. To identify soybean sequences encoding SACPD proteins, we first screened the database for soybean sequences annotated as SACPDs. At least three SACPD-encoding soybean sequences, designated GmSACPD-A, GmSACPD-B, and GmSACPD-C, were available in the database (Table 1). The predicted proteins ranged in length from 386 (GmSACPD-C) to 411 (GmSACPDA and GmSACPD-B) amino acids. TargetP analysis predicted the presence of $\mathrm{N}$-terminal transit peptides targeting the three GmSACPDs to the chloroplast or mitochondria (Emanuelsson et al. 2000). Although GmSACPD-C was predicted to localize to the mitochondria, the difference between the scores for a mitochondrial target peptide versus a plastidal transit peptide was very low (0.06) and the program placed this prediction in the lowest reliability class (Table 1). Both the GmSACPD-A and GmSACPD-B proteins were predicted to localize to plastids; however, the degree of reliability for chloroplast localization was only slightly better than that for mitochondria. Pairwise sequence comparisons revealed that GmSACPD-A and B shared over $98 \%$ of amino acid sequence identity (Fig. 1A) and were placed in the same clade in a neighbor-joining phylogenetic tree. GmSACPD-A differs from GmSACPD-B at seven amino acid positions, including A209T, E257G, N305D, N309S, A312S, V356I, and G374V. GmSACPD-C shared only approximately $64 \%$ sequence identities with SACPD-A and SACPD-B, with differences involving more than 150 amino acid positions.

To determine whether the soybean genome encoded additional SACPD proteins, we screened the Glycine $\max$ expressed sequence transcript (EST) database for sequences with similarities to the Arabidopsis SSI2 protein. In all, 63 different EST with 56 to $93 \%$ sequence identities were obtained. Further analysis of the 63 EST using the soybean gene index at the Computational and Functional Genomics Laboratory, Dana-Farber Cancer Institute showed that these sequences could be combined to yield three distinct sequences designated TC216487 (1,588 bp in length), TC224680 (1,005 bp), and TC205834 (1,736 bp). Sequence comparisons with the three GmSACPDs showed that TC205834 is identical to GmSACPD$C$, with $99.9 \%$ sequence identity, differing in a single nucleotide at position 1,077. The TC216487 sequence is likely identical to $G m S A C P D-B$, sharing $98.6 \%$ of nucleotide sequence identity, with differences at 14 positions. Unlike TC205834 and TC216487, which are full-length sequences, TC224680 is partial and shares highest similarity with the region encoding the C-terminal half of GmSACPD-A. The TC224680 sequence shared nearly $98 \%$ nucleotide identity with $G m-S A C P D-A$ but only $92 \%$ identity to $G m S A C P D-B$. Our analysis indicates that the soybean genome encodes at least three SACPD isoforms whose transcripts are expressed at detectable levels.

To determine the extent of sequence similarities between GmSACPDs and other plant SACPDs, we generated a phylogenetic tree based upon the predicted amino acid sequences of $S A C P D$ s from a variety of plant species (Supplemental Fig. 1). Multiple alignments of all full-length plant $S A C P D$ sequences available in the database (56 different $S A C P D$ s from 30 plant species) showed a high degree of sequence similarity among these proteins. The availability of more than one sequence encoding SACPD from the same plant indicated that many plants carry multiple isoforms of this protein. These included Arabi-

Table 1. Characteristics of the soybean stearoyl-acyl carrier protein-desaturase (SACPD) proteins

\begin{tabular}{lcccccc}
\hline Designation & Accession & Length (amino acids) & Size (kDa) & TP $^{\mathbf{b}}$ & Localization $^{\mathbf{c}}$ & Reliability $^{\mathbf{d}}$ \\
\hline SACPD-A & AAX86050 & 411 & 47.22 & 50 & Choloroplast \\
SACPD-B & AAX86049 & 411 & 47.23 & 50 & Choloroplast \\
SACPD-C & ABM45911 & 386 & 44.02 & 23 & Mitochondria & 4 \\
\hline
\end{tabular}

${ }^{a}$ Amino acid length of the preprocessed protein.

${ }^{\mathrm{b}}$ Predicted amino acid length of N-terminal transit peptide (TP).

${ }^{\mathrm{c}}$ Predicted localization.

${ }^{\mathrm{d}}$ Reliability of the prediction using the Target $\mathrm{P}$ program. 
dopsis, castor, coriander, flax, oilseed rape, rice, sunflower, sesame, soybean, and the black-eyed Susan vine. Multiple sequences from the same organism were denoted with different numbers or letters based upon their annotations in the database, and numbers were assigned if no designations were available. GmSACPD-A and GmSACPD-B form a large cluster with the majority of SACPDs with strong bootstrap support (93\%). Both proteins contain 19 additional amino acids downstream of the terminal leucine residue which is conserved in all the other SACPDs. The third isoform, GmSACPD-C, formed a small, distinct cluster with good bootstrap support with the AtSACPD6 isoform from Arabidopsis (73\% identity), the yellow lupine LISACPD (79\% identity), and the papaya CpSACPD (32\% identity).

\section{Tissue-specific expression of soybean $S A C P D s$.}

In an attempt to characterize $G m S A C P D-A, G m S A C P D-B$, and $G m S A C P D-C$, we examined their expression patterns in various tissues of soybean plants. Reverse-transcriptase poly- merase chain reaction (RT-PCR) analysis using gene-specific primers for $G m S A C P D-C$ showed high levels of transcript in the embryonic axle, moderate levels in root, low levels in flower, and no detectable transcript in leaf and stem tissues (Fig. 2A). GmSACPD-A and GmSACPD-B are very similar in their nucleotide sequences and have been reported to exhibit nearly similar expression patterns in nonseed tissues (Bayfield et al. 2006). Therefore, transcript profiles for GmSACPD-A and $G m S A C P D-B$ were evaluated using a single set of primers. RT-PCR analysis showed expression of GmSACPD-A or $G m S A C P D-B$ genes in all the tissues analyzed, although leaf, flower, and embryonic axle showed higher transcript levels compared with stem and root.

\section{Overexpression of $G m S A C P D-A$ compensates for the loss of the major $S A C P D$ in Arabidopsis.}

To determine the in vivo functionality of the leaf-expressed soybean $S A C P D$ s, we overexpressed GmSACPD-A in WT Arabidopsis plants. Transgenic plants expressing GmSACPD-A
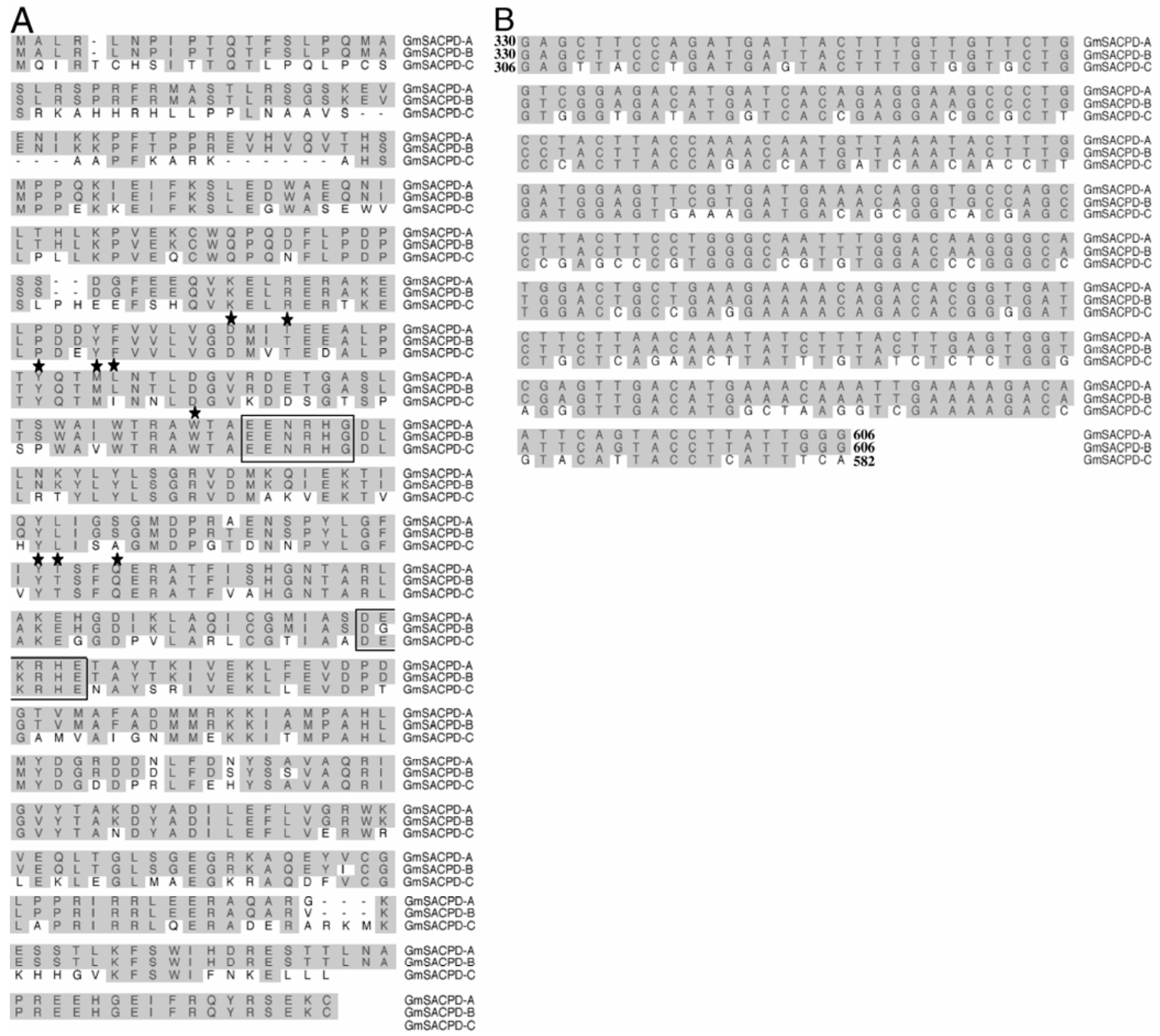

Fig. 1. A, Sequence alignment of the predicted soybean stearoyl-acyl carrier protein-desaturase (SACPD) proteins (A, B, and C). The putative oxygen-binding diiron center responsible for desaturation activity is boxed and the substrate-binding residues are indicated with a star. B, Nucleotide sequence alignment of the region from the three GmSACPDs (A, B, and C) used for generating the silencing vector. Numbers indicate the nucleotide positions. 
(Fig. 3A) under control of the Cauliflower mosaic virus 35S promoter were generated and these showed high levels of GmSACPD-A transcript (Fig. 3C). Analysis of six $\mathrm{T}_{2}$ lines showed that these were morphologically indistinguishable from WT plants and contained WT-like levels of 18:1 (Fig. $3 \mathrm{D})$. We next crossed one of the GmSACPD-A overexpressing lines, designated 35S-SACPDA (SSI2), with ssi2 and scored the $\mathrm{F}_{2}$ plants for segregation of the ssi2 morphology. The $\mathrm{F}_{2}$ population showed skewed segregation from the expected $3: 1$ (WT:ssi2) ratio. PCR analysis of genomic DNA amplified GmSACPD-A only from WT-like plants but not from ssi2-like plants. Furthermore, all WT-like plants that were homozygous for the $s s i 2$ allele contained the GmSACPD-A transgene. These data indicated that overexpression of GmSACPD restored WTlike morphology in the $s s i 2$ background. This was further confirmed by analyzing the segregation of WT-like ssi2 homozygous plants in the $\mathrm{T}_{3}$ generation; the WT-like phenotype cosegregated with the presence of the $S A C P D-A$ transgene. Six plants homozygous for the ssi 2 mutation and overexpressing GmSACPD-A, designated 35S-SACPDA (ssi2), were analyzed. In contrast to ssi2 plants, $35 S-S A C P D A$ (ssi2) plants did not show spontaneous cell death (Fig. 3B) and contained basal levels of the $P R-1$ transcript (Fig. 3C). They also showed WT-like levels of 18:1 (Fig. 3D), suggesting that overexpression of $G m S A C P D-A$ was sufficient to compensate for the loss of SSI2 function in Arabidopsis.

\section{Silencing the GmSACPD-A or GmSACPD-B genes alters morphology and fatty acid profile of soybean plants.}

To determine the effect of loss of SACPD activity in soybean plants, we used our recently developed BPMV-based vector to target $G m S A C P D-A$ or $G m S A C P D-B$ and $G m S A C P D-C$ for silencing in soybean. A 276-bp fragment encoding the region between E110-G202 of GmSACPD-A or GmSACPD-B was cloned into the silencing vector. This sequence corresponded to the sequence encoding E102-S194 of GmSACPD-C and was highly conserved among all three isoforms (Fig. 1B). The BPMV vector (V) and the recombinant vector targeting $G m S A C P D s$ (D) were inoculated onto soybean plants. cDNA was prepared from leaf, stem, flowers, root, and embryonic axle of seed from V or D plants and RT-PCR analysis was used to evaluate the transcript levels of BPMV, GmSACPD-A or
A

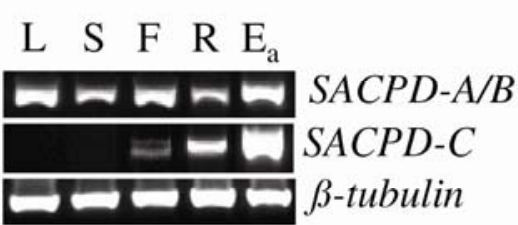

B

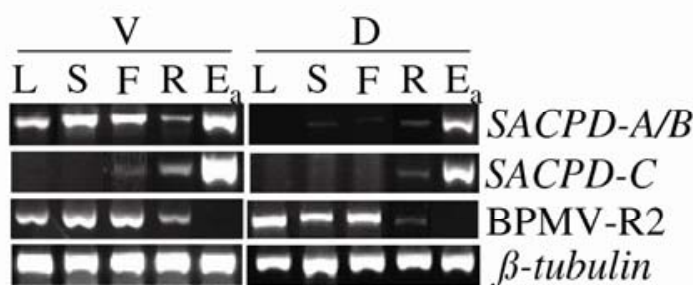

C

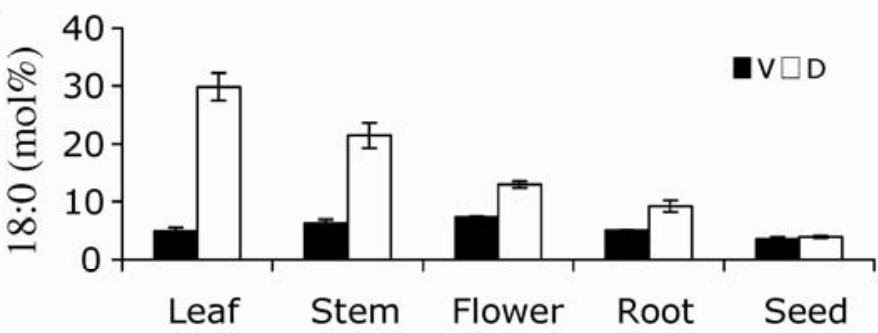

$\mathrm{D}$

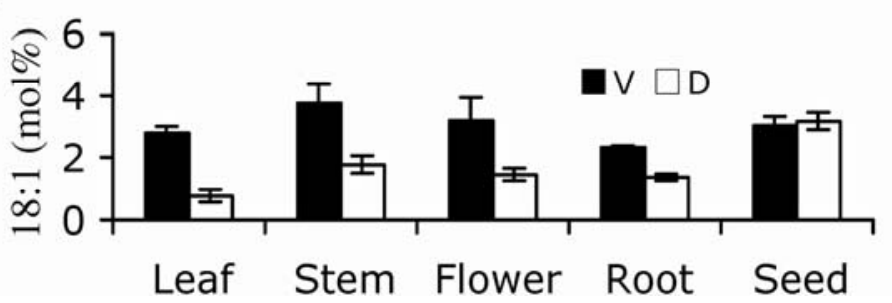

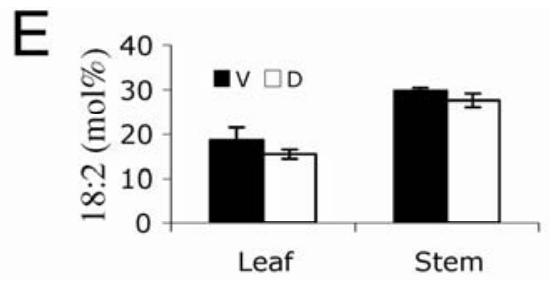
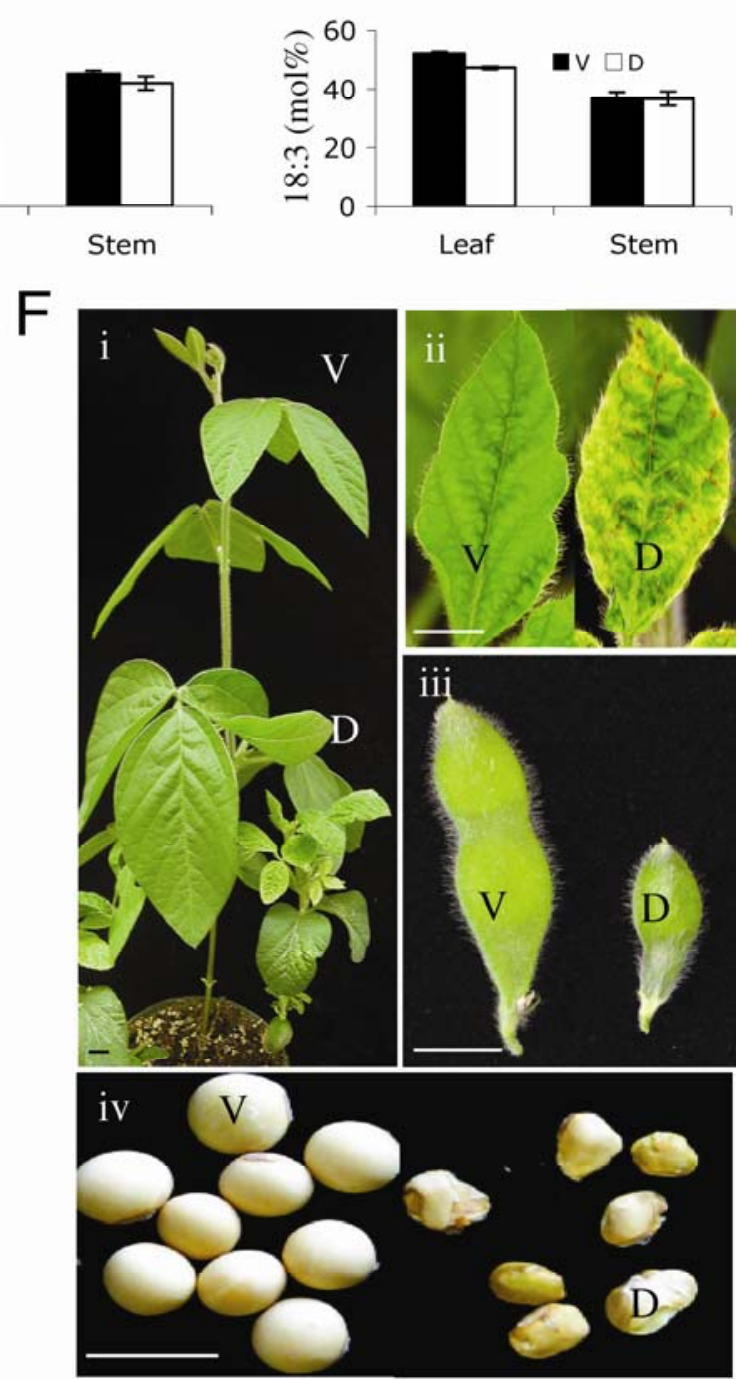

Fig. 2. Tissue-specific expression of stearoyl-acyl carrier protein-desaturase genes (SACPDs). A, Reverse-transcriptase polymerase chain reaction (RT-PCR) analysis to detect expression of the three GmSACPDs in leaf $(\mathrm{L})$, stem $(\mathrm{S})$, flower $(\mathrm{F})$, root $(\mathrm{R})$, and embryonic axle $\left(\mathrm{E}_{\mathrm{a}}\right)$ tissues of healthy soybean plants. B, Expression of GmSACPDs and Bean pod mottle virus RNA2 (BPMV-R2) in leaf (L), stem (S), flower (F), root (R), and embryonic axle (E) of vector-inoculated plants (V) or plants silenced for $G m S A C P D-A / B$ (D) as detected by RT-PCR. Levels of $\beta$-tubulin were used as internal control to normalize the amount of cDNA in each reaction. C, Levels of 18:0 and D, levels of 18:1 in various tissues of V (solid bars) and D (open bars) plants. E, Levels of 18:2 and 18:3 in leaf and stem tissues of V (solid bars) and D (open bars) plants. Fatty acid levels are shown as mol\% and bars represent standard deviation of the mean where $n=5$. F, Morphology of whole plants (i), leaf (ii), pod (iii), and seed (iv) of V and D plants. Scale bars represent $1 \mathrm{~cm}$. 
GmSACPD-B and GmSACPD-C, and $\beta$-tubulin, from these tissues. A high amount of viral transcript was detected in leaf, stem, and flower tissues. In comparison, lower viral transcript levels were detected in root tissue, while no transcript was detected in the embryonic axle from seed of $\mathrm{V}$ and $\mathrm{D}$ plants harvested at maturity (Fig. 2B). Expression profiles for GmSACPD$A$ or $G m S A C P D-B$ and $G m S A C P D-C$ in V plants were similar to those in mock-inoculated (M) plants (Fig. 2B and A, respectively). As inferred from viral transcript levels, GmSACPD-A or $G m S A C P D-B$ transcripts were greatly reduced in stem and flower tissues and undetectable in leaves of D plants. In contrast, reduction in transcript levels was less evident in root and embryonic axle of D plants. The $G m S A C P D-C$ expression also was effectively silenced (no transcript was detected) in flowers from D plants. However, the expression of $G m S A C P D-C$ in root or embryonic axle tissues of $\mathrm{V}$ and $\mathrm{D}$ plants was nearly comparable (Fig. 2B). These data show that silencing of the $G m S A C P D$ isoforms was successfully achieved in all tissues where BPMV was detected.
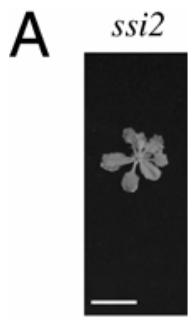

B
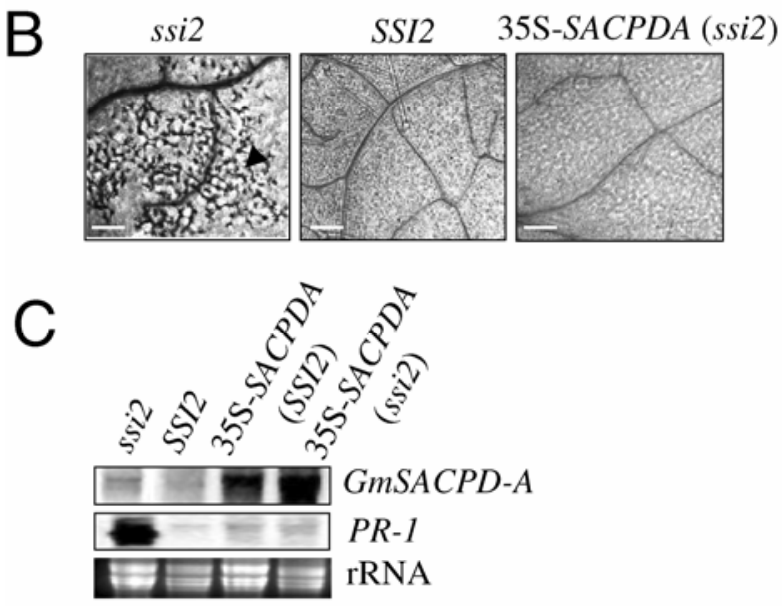

D

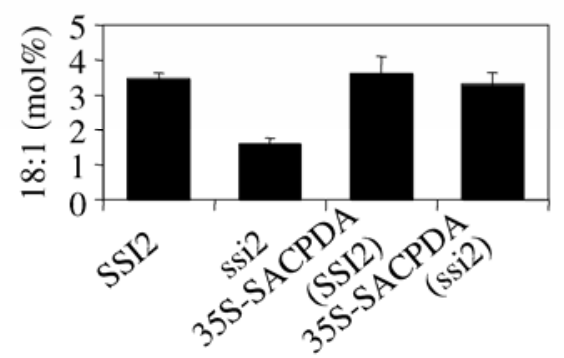

Fig. 3. Effect of overexpressing soybean stearoyl-acyl carrier protein-desaturase genes (GmSACPD-A-35S) in wild-type (SSI2) and mutant (ssi2) Arabidopsis plants (SACPDA). A, Morphological phenotypes of 4-weekold soil-grown Arabidopsis plants. Scale bar represents $1 \mathrm{~cm}$. B, Microscopy of trypan-blue-stained leaves of indicated genotypes. Cell death in ssi 2 plants is indicated by an arrow head. Scale bars represent $270 \mathrm{mi}-$ crons. C, Northern blot analysis to detect GmSACPD-A or pathogenesisrelated $(P R)-1$ gene expression in indicated genotypes. D, Levels of 18:1 in indicated genotypes. Fatty acid levels are shown as mol\%. Bars indicate standard deviation of the mean where $n=6$.
Because a mutation in the Arabidopsis SACPD isoform SSI2 alters levels of stearic acid (18:0) and 18:1 in the mutant plants, we analyzed D plants for their FA profiles. Both $\mathrm{V}$ and $\mathrm{M}$ plants showed similar FA profiles, suggesting that BPMV infection did not significantly alter FA levels in soybean leaves (data not shown). By comparison, leaf tissue from D plants showed an approximately sixfold increase in 18:0 levels and an approximately 3.6-fold reduction in 18:1 levels compared with $\mathrm{V}$ plants (Fig. 2C and D). Consistent with the RT-PCR data, silencing of $G m S A C P D-A$ or $G m S A C P D-B$ also resulted in an increase in 18:0 levels and a decrease in 18:1 in stem, flower and root tissues but not in seed from D plants. As expected, alterations in 18:0 and 18:1 levels were less prominent in roots compared with leaf or stem. Although the D plants contained greatly reduced 18:1 levels, they showed normal levels of 18:2 or 18:3 compared with V plants (Fig. 2E).

A mutation in SSI2 results in pronounced stunted phenotype and the appearance of visible cell death lesions on leaves in Arabidopsis (Kachroo et al. 2001). Interestingly, silencing of GmSACPDs produced similar phenotypes in soybean; D plants showed severely stunted phenotype, altered leaf morphology, and the appearance of necrotic lesions on leaves (Fig. 2F, panels $\mathrm{i}$ and ii). By comparison, inoculation of BPMV produced only virus-related mottling symptoms on soybean plants, and these plants were only moderately smaller than the noninoculated or M plants. The D plants also produced pods that were markedly reduced in size compared with those from $\mathrm{V}$ plants (Fig. 2F, panel iii); consequently, both seed size and morphology of D plants were distinctly different from V plants (Fig. $2 \mathrm{~F}$, panel iv).

\section{Silencing of $G m S A C P D-A$ or $G m S A C P D-B$ alters $P R$ gene expression, $S A$ levels, and $R$ gene expression in soybean.}

The Arabidopsis ssi2 mutant contains high levels of SA and exhibits increased expression of $P R$ genes (Kachroo et al. 2001). To examine whether the loss of SACPD function also induced similar defense-related phenotypes in soybean, we carried out molecular and cytological analysis of V and D plants. Microscopic cell death lesions and elevated levels of reactive oxygen species (ROS) were detected in the leaves of D plants (Fig. 4A). By comparison, leaves from V plants exhibited no cell death lesions (visual or microscopic) and carried only basal levels of ROS. The D plants also showed elevated expression of several $P R$ genes, including $P R I, P R l a$, $P R P$, and $P R 3$ (Fig. 4B). Because overexpression of the soybean calmodulin genes, $S C a M-4$ and $S C a M-5$, resulted in increased $P R$ gene induction in transgenic tobacco and Arabidopsis (Heo et al. 1999; Park et al. 2004), we analyzed the levels of their transcripts in D plants. Indeed, the induced expression of $P R$ genes coincided with increased transcript levels for SCaM-4 and-5 in D plants (Fig. 4C). Increase in $S C a M-5$ transcript levels was more prominent than that for $S C a M-4$. Both PRI and PRP are known to be SA inducible (He et al. 2002; Mazarei et al. 2007); therefore, we next determined the levels of free and bound SA in M, V, and D plants. Inoculation of soybean seedlings with BPMV resulted in an approximately twofold increase in the free SA levels and only a slight increase in the levels of SA-glucoside (SAG) (Fig. 4D and E). On the other hand, leaves from D plants showed an approximately 2.4 -fold increase in their SA levels and an approximately 2.8-fold increase in SAG levels compared with M plants.

Our recent work with the ssi2 mutant has shown that reduced 18:1 levels can induce a variety of $R$ genes in Arabidopsis (Chandra-Shekara et al. 2007). Because silencing of GmSACPDs also resulted in the reduction of 18:1 levels in the 
D plants, we analyzed the expression of several $R$-like soybean genes in $\mathrm{V}$ and $\mathrm{D}$ plants. In soybean, several genes have been predicted to encode $\mathrm{R}$ proteins based upon the presence of sequences encoding nucleotide-binding leucine-rich repeat (NBLRR) domains (Ashfield et al. 2003; Bhattacharyya et al. 2005; Gao et al. 2005; Graham et al. 2002; Hayes et al. 2004; Yu et al. 1996). We chose to analyze $R$ genes known or predicted to confer resistance against Pseudomonas syringae (Rpg1b/AY452685), Phytophthora sojae (Rps1-K-2/ AY963293), and Soybean mosaic virus (Rsv1/AY518517, AY518518, and AY518519), and $R$ gene analogs that encoded proteins containing either a toll-interleukin (TIR)-like (AF175399, BI425148, and BE584264) or non-TIR-like (AY278773, AF314550, and AF322633) domain in the N-terminal region. RT-PCR analysis did not detect transcripts for 6 of the 11 genes tested; however, the remaining 5 genes showed elevated transcript levels in D plants (Fig. 4F). Together, these results suggest that silencing of $G m S A C P D$ alters soybean defense responses, similar to that observed in Arabidopsis plants carrying genetic mutations in the orthologous gene.

\section{Exogenous application of glycerol mimics the effect of silencing $G m S A C P D s$ in soybean.}

Previously, we have shown that exogenous application of glycerol lowers 18:1 levels and mimics the ssi2-induced phenotypes in Arabidopsis (Chandra-Shekara et al. 2007; Kachroo et al. 2004, 2005). To determine whether glycerol application also lowered 18:1 levels in soybean and mimicked phenotypes produced upon silencing of GmSACPD, we treated soybean plants with water and glycerol and monitored the changes in 18:1 levels and the induction of defense phenotypes. Soybean plants were sprayed with 50 to $300 \mathrm{mM}$ glycerol or water and FAs were extracted 1 to 5 days posttreatment. The 18:1 levels were reduced progressively, with increased concentration of glycerol (Fig. 5A, data shown for 4 days posttreatment). Monitoring the treatment over time showed that 18:1 levels declined progres-

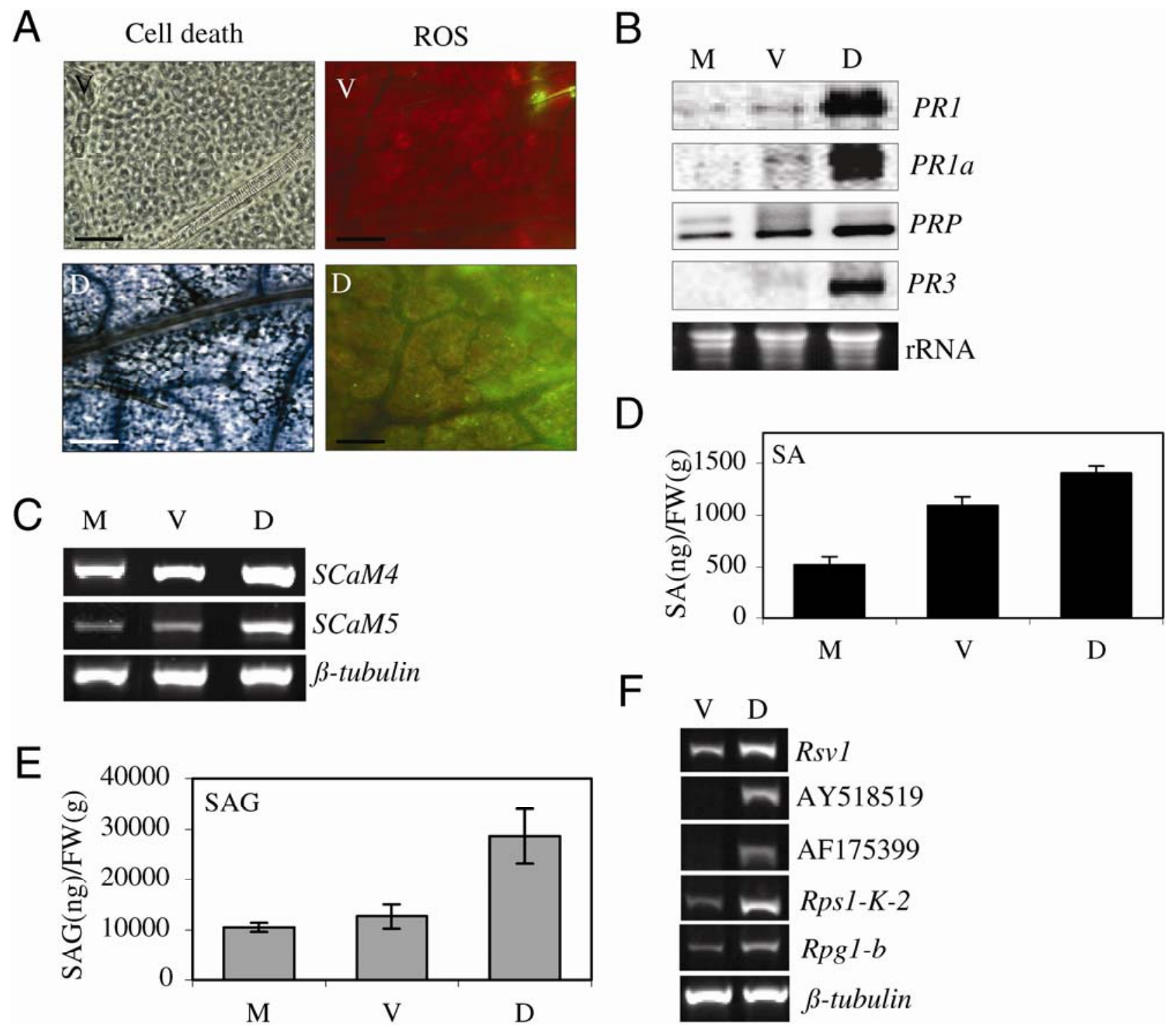

Fig. 4. Cell death, pathogenesis-related $(P R)$ gene expression, accumulation of salicylic acid (SA), and the expression of a variety of resistance $(R)$ genes in soybean plants silenced for $G m S A C P D-A$ or $-B(\mathrm{D})$, mock (M), or vector (V) -inoculated plants. A, Microscopy of trypan-blue-stained leaves to detect cell death, and leaves infiltrated with dichlorodihydroflourescein diacetate to detect reactive oxygen species (ROS) production. Scale bars represent 270 microns. B, PR1, PRla, proline-rich protein $(P R P)$, and PR3 gene expression as detected by Northern blot analysis. Ethidium bromide staining of rRNA is used as a loading control. C, SCAM4 and 5 gene expression as detected by reverse-transcriptase polymerase chain reaction (RT-PCR). D, Endogenous SA and E, SAglucoside (SAG) levels. Bars represent standard deviation of the mean where $n=3$. F, RT-PCR analysis of various $R$ genes. Levels of $\beta$-tubulin were used as internal control to normalize the amount of cDNA in each reaction. 
sively with time and this decline was more rapid with higher concentrations of glycerol (data not shown). The reduction in 18:1 levels leveled off at glycerol concentrations higher than 100 $\mathrm{mM}$; therefore, all subsequent experiments were carried out using $100 \mathrm{mM}$ glycerol. Exogenous application of glycerol resulted in the appearance of visible and microscopic cell-deathlike lesions on treated leaves (Fig. 5B). Control plants treated with water, $100 \mathrm{mM}$ sorbitol, or $100 \mathrm{mM}$ mannitol did not exhibit cell death or significant alterations in their FA profiles (Fig. $5 \mathrm{~B}$ and $\mathrm{C}$ ). The glycerol-induced appearance of cell-death lesions also correlated with an increase in the ROS levels (Fig. $5 \mathrm{~B})$ and the induction of $P R 1$ and PRIa expression in treated plants (Fig. 4C). In contrast to SA-responsive genes, glycerol application did not induce the expression of jasmonic acid- responsive genes such as $V s p B$ (Fig. 4C). Similar to results obtained with the D plants, application of glycerol also induced the expression of SCaM-4 and SCaM-5 (Fig. 5D). Increased $P R$ gene expression also correlated with an approximately 2- to 2.5fold increase in the SA and SAG levels in glycerol-treated plants (Fig. 5E and F). These results show that glycerol application induced phenotypes that mimic those related to the silencing of $G m S A C P D s$ in soybean, and that glycerol-mediated defense signaling is conserved between Arabidopsis and soybean.

\section{Glycerol application and silencing of GmSACPDs confers} enhanced resistance to bacterial and oomycete pathogens.

To determine whether the induction of constitutive defenses either via silencing of $G m S A C P D$ or the exogenous application
A

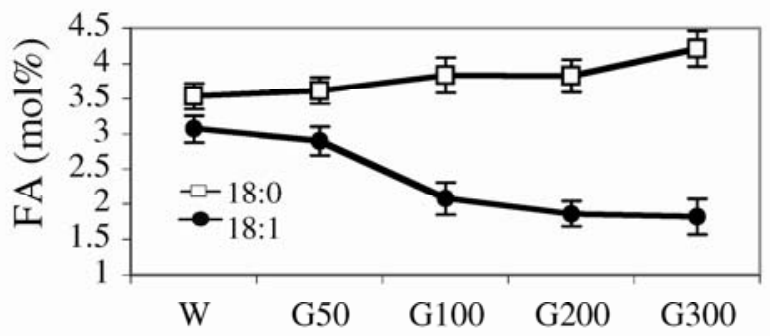

B

Cell death
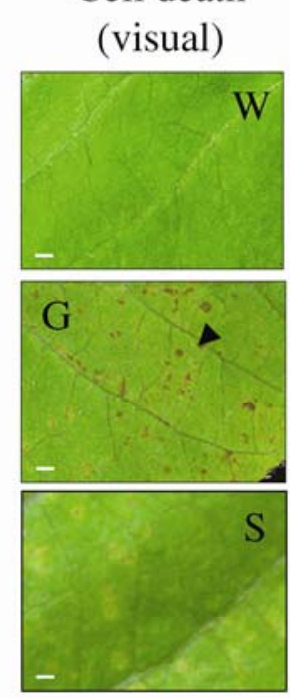

$\mathrm{S}$
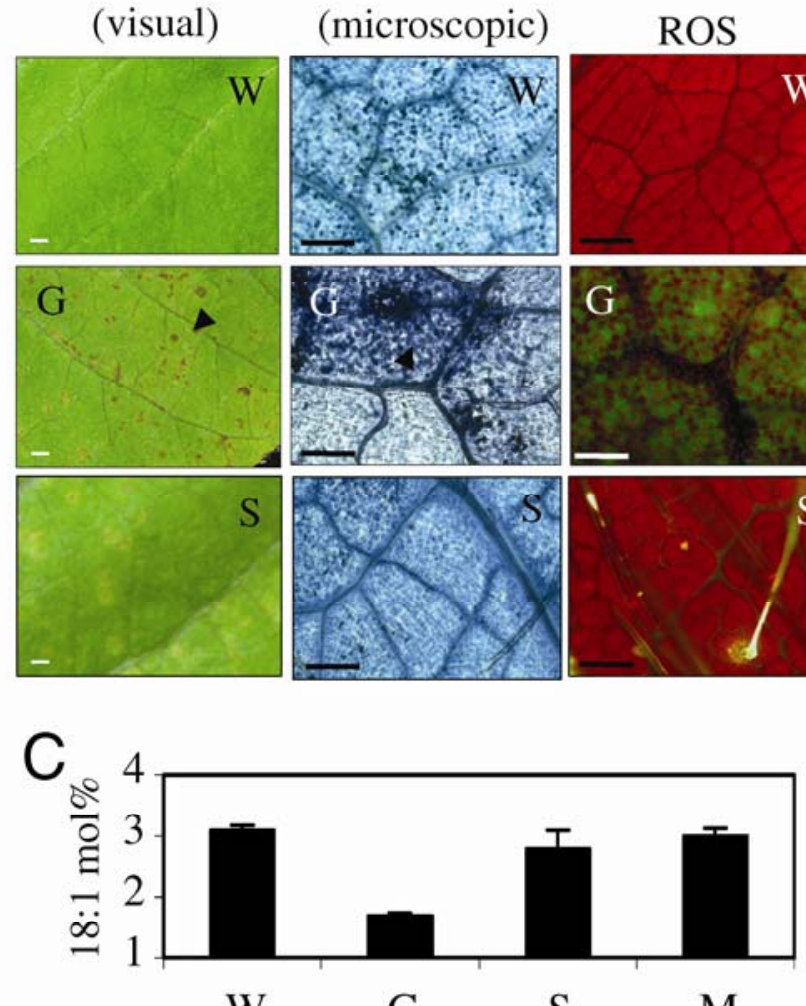
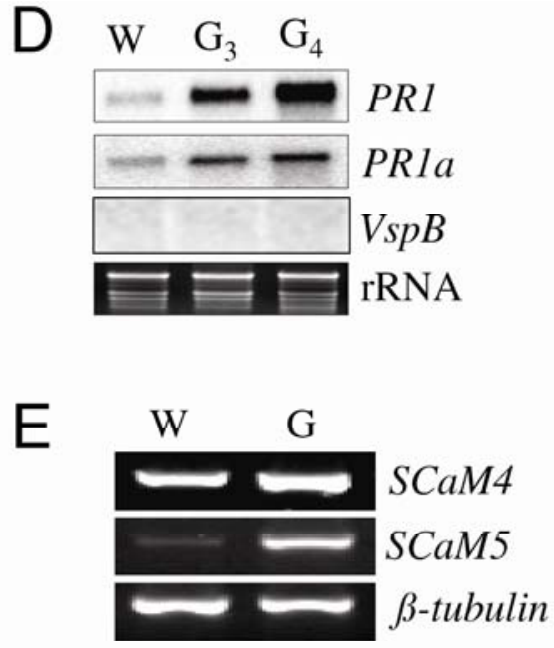

$\mathrm{F}$

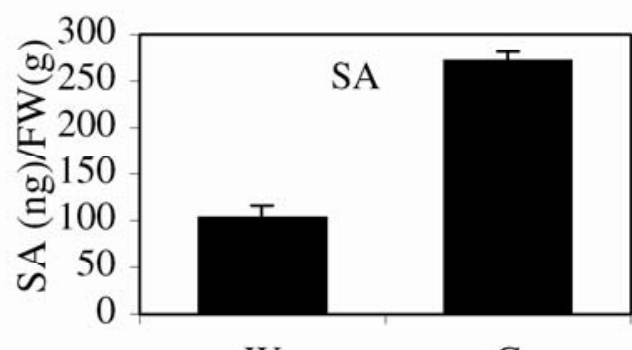

W

$\mathrm{G}$

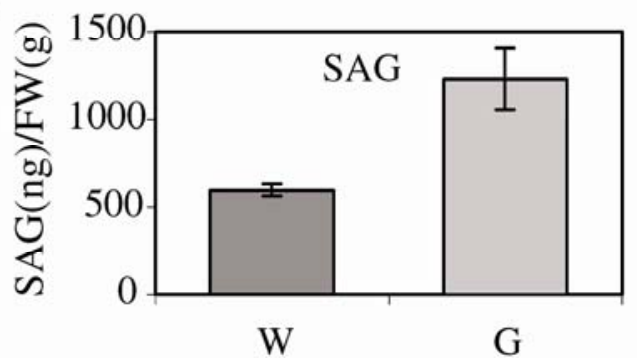

Fig. 5. Effect of exogenous glycerol treatment on soybean fatty acid (FA) content, cell death, and reactive oxygen species (ROS) production, pathogenesisrelated $(P R)$ gene expression, and salicylic acid (SA) levels. A, Glycerol-induced changes in 18:0 (open squares) and 18:1 (closed circles) content in soybean leaf tissue after treatment with 50 (G50), 100 (G100), 200 (G200), and $300 \mathrm{mM}$ glycerol (G300) compared with the water (W) treatment. FA levels were determined by gas chromatography (GC) analysis. Bars indicate standard deviation of the mean where $n=6$. B, Glycerol-induced cell death is detectable visually and microscopically, as indicated by arrowhead. ROS production is detected by visualizing fluorescence due to $2^{\prime}, 7^{\prime}$-dichlorodihydroflourescein diacetate infiltration. Plants treated with water (W) or $100 \mathrm{mM}$ sorbitol (S) do not exhibit similar cell death symptoms. Scale bars represent $1 \mathrm{~mm}$ in photographs and 270 microns in micrographs. C, Levels of 18:1 in leaves of plants treated with water (W) or $100 \mathrm{mM}$ each of glycerol (G), sorbitol (S), or mannitol (M). FA levels were determined by GC analysis. Bars indicate standard deviation of the mean where $n=6$. D, PRl, PRla, and VspB expression 3 or 4 days $\left(\mathrm{G}_{3}\right.$ or $\mathrm{G}_{4}$, respectively) after treatment with $100 \mathrm{mM}$ glycerol or 4 days after treatment with water $(\mathrm{W})$. E, Reverse-transcriptase polymerase chain reaction analysis of SCAM4 and 5 genes. Levels of $\beta$-tubulin were used as internal control to normalize the amount of cDNA in each reaction. F, Endogenous SA and G, SA-glucoside (SAG) levels. The values are presented as the mean of three replicates. Bars represent standard deviation of the mean where $n=3$. 
of glycerol confers enhanced resistance against virulent pathogens, we challenged water (W)- or glycerol (G)-treated plants and $\mathrm{V}$ or $\mathrm{D}$ plants with virulent bacteria and oomycete pathogens. Inoculation with Pseudomonas syringae pv. glycinea showed that $\mathrm{V}$ plants were 10 -fold more susceptible to bacteria compared with M plants (Fig. 6A). In comparison, D plants exhibited enhanced resistance, with an approximately 30-fold reduction in their bacterial titer. Exogenous application of glycerol also led to an approximately 15 -fold reduction in bacterial growth compared with the W plants (Fig. 6B).

To assess the response to an oomycete pathogen, we inoculated $\mathrm{V}$ and D plants with $P$. sojae. Inoculation of $P$. sojae produced necrotic lesions on $\mathrm{V}$ plants which increased in size and progressed extensively throughout the stem (Fig. 6C and E). Compared with $\mathrm{V}$, the $\mathrm{D}$ plants produced much smaller lesions which were greatly restricted in their spread (Fig. 6C and E). This suggested that a reduction in 18:1 conferred enhanced resistance to $P$. sojae. Enhanced resistance in response to low 18:1 was further confirmed by inoculating W- and G-treated plants with $P$. sojae. As expected, exogenous application of glycerol led to a significant reduction in the size and spread of $P$. sojae-induced necrotic lesions (Fig. 6E). The W plants succumbed rapidly to $P$. sojae infection and were killed within 5 days of inoculation. In contrast, $G$ plants exhibited greatly reduced susceptibility and more than $80 \%$ of $G$ plants were able to survive infection by $P$. sojae (Fig. 6D). Our results suggest that exogenous application of glycerol or silencing of $G m S A C P D$ confers enhanced resistance to bacterial and oomycete pathogens.

\section{DISCUSSION}

SACPDs are essential enzymes catalyzing the formation of the monounsaturated FA, 18:1, in plants. The functional importance of these proteins is underscored by the large extent of sequence conservation within SACPD proteins from diverse plant species. Even though these proteins are highly similar in sequence, they likely function to fulfill distinct physiological functions. This is illustrated by the observations that basal expression of other isoforms are unable to compensate for the loss of the major SACPD in Arabidopsis (Kachroo et al. 2007), and that the various isoforms exhibit different specific activities for 16:0- or 18:0-acyl carrier protein (ACP) substrates (Kachroo et al. 2007). Although our results suggest that the reduction of 18:1 levels in GmSACPD-silenced plants is associated with the lowered expression or loss of expression of $G m S A C P D-A$, $G m S A C P D-B$, or $G m S A C P D-C$, it is quite likely that silencing also affected the transcript levels of other, yet uncharacterized, soybean SACPD genes. However, this is unlikely given that the soybean EST database does not contain additional $S A C P D$-like sequences that are significantly different from GmSACPD-A, GmSACPD-B, or GmSACPD-C.

Previously, we have shown that high expression of a lowspecific-activity Arabidopsis isozyme (AtSACPD1) compensates for the loss of SSI2 function (Kachroo et al. 2007). Similarly, overexpression of GmSACPD-A also restored all the defense phenotypes in ssi2 by increasing 18:1 levels. Thus, it is reasonable to argue that GmSACPD-A can utilize 18:0-ACP as a substrate with at least as much specific activity for 18:0-ACP as AtSACPD1. Indeed, previous biochemical analysis of an SACPD from soybean showed that the recombinant protein was able to utilize both 18:0-ACP as well as palmitoyl (16:0)ACP substrates with $>100$-fold greater specific activity for 18:0-ACP (Gibson 1993). Arabidopsis plants overexpressing the high-specific-activity SACPD, SSI2, fail to accumulate increased levels of 18:1 (Kachroo et al. 2007), suggesting that SACPD activity is tightly regulated in these plants. Similar
A

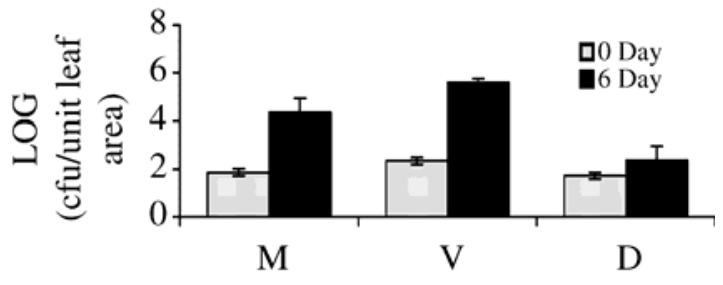

B

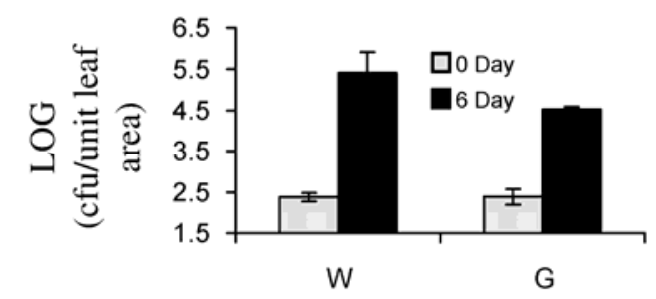

C

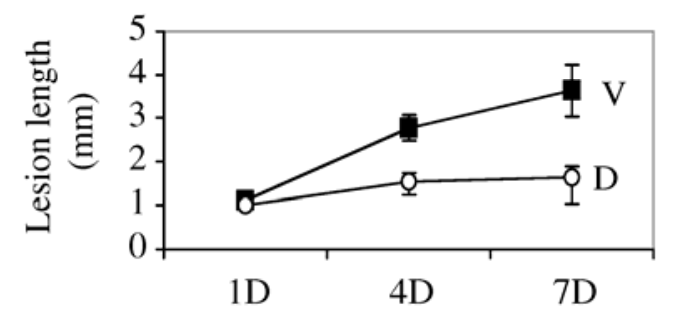

D

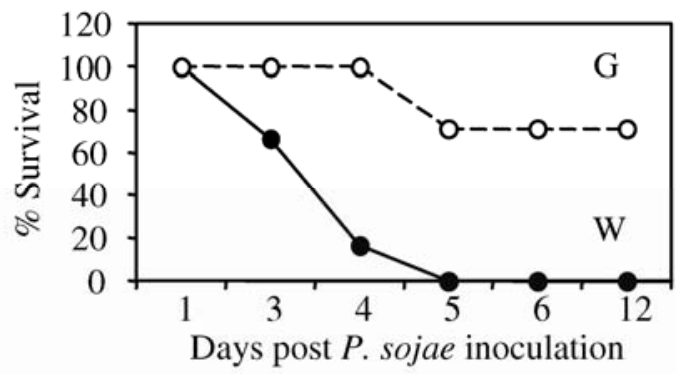

E

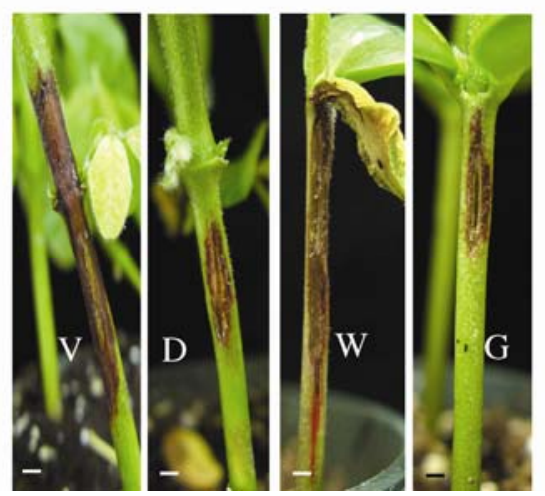

Fig. 6. Effect of silencing soybean stearoyl-acyl carrier protein-desaturase gene $(G m S A C P D)$ and exogenous glycerol treatment on soybean response to infection by virulent strains of Pseudomonas syringae pv. glycinea and Phytophthora sojae. A, Bacterial growth on mock- (M) or vector- (V) inoculated plants compared with plants silenced for $G m S A C P D$ (D). B, Bacterial growth on plants treated with water (W) or glycerol (G). Bacterial numbers were titered by culturing extracts of four leaf discs from infected leaves at 0 (gray bars) or 6 (black bars) days postinoculation and are presented as the LOG of CFU per unit leaf area. Bars indicate standard deviation of the mean where $n=5$. C, $P$. sojae disease progression on $\mathrm{V}$ (closed squares) or D (open circles) plants, as measured in lesion length (mm), 1 (1D), 4 (4D), or 7 (7D) days postinoculation. D, Resistance in W (open circles) or $\mathrm{G}$ (closed circles) -treated plants, 1, 3, 4, 5, 6, and 12 days postinoculation, calculated as the percentage of plants surviving $P$. sojae infection. Values are presented as the average of three independent replicates. Bars indicate standard deviation where $n=5$. E, P. sojae lesion morphology on $\mathrm{V}$ or $\mathrm{D}$ plants 7 days postinoculation, and on $\mathrm{W}$ or $\mathrm{G}$ plants $96 \mathrm{~h}$ postinoculation. Scale bars represent $1 \mathrm{~mm}$. 
inability of Arabidopsis plants overexpressing GmSACPD-A to increase 18:1 levels beyond basal levels suggests that substrate or cofactor limitations or feedback regulation of SACPD enzymes in Arabidopsis also is applicable to orthologous soybean proteins. This is particularly interesting because Arabidopsis and soybean utilize distinctly different FA biosynthetic pathways (Roughan 1987). Plants such as Arabidopsis can desaturate $16: 0$ to $16: 3$ via the chloroplast-derived prokaryotic pathway and, thereby, are capable of incorporating C16 FAs in their glycerolipids (Browse et al. 1986; Roughan and Slack 1984). In contrast, an 18:3 plant such as soybean only can initiate unsaturated FA synthesis via the SACPD-catalyzed reaction. Thus, 18:3 plants lack lipid moieties containing 16:3 acyl groups. Previous reports have suggested that the altered defense-related phenotypes in ssi2 plants might be associated with 16:3 levels in these plants (Nandi et al. 2003), rather than the reduced 18:1. However, GmSACPD-silenced soybean plants show altered defense signaling, even though they lack 16:3 FAs (Heinz and Roughan 1983). Our current work, together with previous studies (Kachroo et al. 2003b, 2004, 2005, 2007), unequivocally refutes the possibility that 16:3 levels are associated with the altered defense phenotypes resulting from loss of SACPD activity.

Although the GmSACPD-silenced plants contained greatly reduced levels of 18:1, they were not altered in the levels of 18:2 or 18:3 FAs. These results are similar to those obtained with Arabidopsis, where ssi2 plants carry WT-like levels of 18:2 and 18:3 FAs (Kachroo et al. 2001). Furthermore, analysis of ssi2 suppressor mutants in various FA metabolic mutant backgrounds has shown that restoration of altered defense signaling is not associated with further desaturation of $18: 1$ to 18:2 or 18:3 in plastidal or extraplastidal lipids (Kachroo et al. 2005). Because silencing GmSACPDs induces ssi2-like phenotypes in soybean, it is likely that, similar to Arabidopsis, defense signaling in soybean also is modulated by reduced 18:1 levels.

Low 18:1-induced cell death; increase in SA, $P R$, and $R$ gene expression; and resistance to pathogens in soybean suggest that components of the 18:1-regulated defense signaling pathway are likely to be conserved between soybean and Arabidopsis. Interestingly, reduced 18:1 also induced the expression of two defense-related calmodulin genes, SCAM-4 and SCAM5 (Fig. 3). Overexpression of the SCAM-4 and SCAM-5 genes in Arabidopsis or tobacco induces $P R$ gene expression and confers enhanced resistance to multiple pathogens in an SAdependant manner (Heo et al. 1999; Park et al. 2004), suggesting that SCAM-4 and SCAM-5 may participate in the low-18:1derived defense signaling pathway. However, this possibility is unlikely because the low-18:1-mediated alterations in defense phenotypes are SA independent, at least in Arabidopsis (Kachroo et al. 2001, 2003). Further studies using soybean plants carrying reduced SA will help decipher the role of $S C A M-4$ and SCAM-5 in mediating 18:1-derived defense signaling.

Reduced 18:1 levels could modulate defense signaling by either directly altering the expression of various defense-associated genes or affecting the activities of the encoded proteins. Transcriptional regulation may result from the direct induction or suppression of transcriptional activators or suppressors, respectively. For example, the 18:1-mediated activation of a transcription factor is known to induce genes required for neuronal differentiation (Rodríguez-Rodríguez et al. 2004). Similarly, in Saccharomyces cerevisiae and mammalian cells, binding of 18:1 to specific transcription factors induces the transcription of genes carrying 18:1 responsive elements in their promoters (Karpichev and Small 1998; Rottensteiner et al. 2003). On the other hand, expression of the oncogene HER2 is inhibited via the 18:1-upregulated expression of its transcriptional repressor (Menendez and Lupu 2006). Post-translational regulation might be achieved by directly activating, inhibiting, or altering protein activities. For example, 18:1 is known to activate phospholipase D in Arabidopsis (Wang and Wang 2001) and inhibit glucose-6-phosphate transporter activity in Brassica embryos (Fox et al. 2000). An example of altered activity is the human $\propto$-lactalbumin which, in its 18:1-conjugated form, induces apoptotic cell death specifically in tumor cells (Svanborg et al. 2003). Characterization of downstream components of this 18:1-regulated pathway in plants would help decipher this novel mode of defense activation. Understanding this pathway eventually could aid the development of robust crop protection strategies.

Our work also emphasizes the usefulness of the BPMV vector as a viable and valuable tool for carrying out functional genomics in soybean. Molecular analysis of transcript levels in silenced plants showed that this novel vector may be employed to effectively silence genes expressed in all tissues where BPMV can be detected; namely, leaf, stem, flower, and, to a lesser extent, roots. Furthermore, we recently have been able to utilize this BPMV-based vector to assign defense-related functionalities to several other soybean sequences (D.-Q. Fu, S. A. Ghabrial, and A. Kachroo, unpublished data). The availability of the BPMV vector and its demonstrated efficacy has opened up exciting new possibilities for gene function studies in soybean.

\section{MATERIALS AND METHODS}

\section{Plant growth conditions.}

Soybean (G. $\max ($ L.) Merr.) plants of cvs. Harosoy or Essex were grown in the greenhouse with day and night temperatures of 25 and $20^{\circ} \mathrm{C}$, respectively. Inoculation with recombinant BPMV vectors was carried out at the VC stage (Pedersen 2004). Vector-inoculated (V) or GmSACPD-silenced (D) plants were analyzed for various phenotypes at approximately V3 growth stage. At least six to eight plants were inoculated with vector or the desaturase-silencing construct for each set of experiments. Analysis of the effect of silencing was carried out using three to four separate sets of silenced plants for each phenotype. Arabidopsis plants were grown in the MTPS 144 Conviron walk-in chambers at $22^{\circ} \mathrm{C}, 65 \%$ relative humidity, and a 14-h photoperiod.

\section{Construction of viral vectors, in vitro transcription, and plant inoculation.}

For generating silencing vectors, a 276-bp DNA fragment encoding GmSACPD-A or GmSACPD-B was amplified from soybean cDNA using sequence-specific primers with BamHI and $M s c$ I sites, forward 5'-GCATGGATCCGAGCTTCCAGA TGATTACTT-3' and reverse 5'-CAGTTGGCCACCCAATAA GGTACTGAATTG-3'. PCR products were digested with these restriction enzymes and ligated to the BamHI- and $M s c \mathrm{I}-$ digested pGG7R2-V (Zhang and Ghabrial 2006). Plasmid constructs were used for in vitro transcription as previously described (Gu and Ghabrial 2005). Briefly, capped RNA transcripts were synthesized by incubating 1 to $5 \mu \mathrm{g}$ of linearized plasmids in a $100-\mu 1$ reaction mixture containing $40 \mathrm{mM}$ Tris$\mathrm{HCl}, \mathrm{pH} 7.5 ; 6 \mathrm{mM} \mathrm{MgCl} 2 ; 2 \mathrm{mM}$ spermidine; $10 \mathrm{mM}$ dithiothreitol; 50 units of RNasin (Promega Corp., Madison, WI, U.S.A.); $0.5 \mathrm{mM}$ each ATP, CTP, and UTP; $0.1 \mathrm{mM}$ GTP; 0.5 $\mathrm{mM}$ cap-analogue $\left(\mathrm{m}^{7} \mathrm{G}\left[5^{\prime}\right] \mathrm{G}\right)$ (New England Biolabs, Ipswich, MA, U.S.A.]; and 50 units of T7 RNA polymerase (New England Biolabs) at $37^{\circ} \mathrm{C}$ for $2 \mathrm{~h}$. Yield and integrity of the transcripts were analyzed by electrophoresis on a $1.0 \%$ agarose gel. RNA transcripts (RNA1 from strain K-Hol and recombi- 
nant RNA2) were used to rub inoculate fully expanded unifoliate leaves of soybean (VC stage).

\section{Plant transformation.}

Full-length cDNA corresponding to $G m S A C P D-A$ was PCR amplified using sequence-specific primers linked to the NcoI $\left(5^{\prime}\right)$ and XhoI (3') sites and cloned downstream of a double $35 \mathrm{~S}$ promoter in pRTL2-GUS (Restrepo et al. 1990). The fragment containing the promoter $G m S A C P D-A$ cDNA and terminator was removed from pRTL2-SACPD-A as a $P s t$ f fragment and cloned into the binary vector pCAMBIA1305. Transformation constructs were introduced into Agrobacterium tumefaciens MP90 by electroporation and used to transform Arabidopsis by the floral dip method (Clough and Bent 1998). Transformants were selected by growth on media containing hygromycin at $17 \mu \mathrm{g} / \mathrm{ml}$.

\section{RNA extraction and Northern and RT-PCR analysis.}

RNA from leaf, stem, and root tissues of soybean plants at V1 or V2 growth stage and flower tissues at R1 stage was extracted using the TRIzol reagent (Invitrogen, Carlsbad, CA, U.S.A.), as per the manufacturer's instructions. RNA from detached embryonic axles was extracted after soaking seed from M, V, or D plants in sterile water overnight. For silencing experiments, RNA was extracted from BPMV-inoculated plants at V3 stage. Northern blot analysis and synthesis of randomprimed probes was as described before (Kachroo et al. 2001). Reverse transcription and first-strand cDNA synthesis was carried out using Superscript II (Invitrogen). Two to three independent RNA preparations were analyzed at least twice by RTPCR (35 amplification cycles), using forward 5'-GGACGTCG AGACTCCAAAAGGTTCCAT-3' and reverse 5'-AATTTAAA TAGATTTGTTTCCATTTGAGC-3' primers for BPMV-RNA2 or primers specific to the full-length coding sequence of GmSACPDs (Table 1). The number of amplification cycles was reduced to 23 to 25 for evaluating the relative difference in transcript levels in various samples.

\section{Primers, sequence accessions, and phylogenetic analysis.}

Primers were designed for full-length coding sequences available in the database, including GmSACPDs (Table 1), PRl (AI930866), PRla (AF136636), PRP (AF248055), PR3 (AF202731), $\beta$-tubulin (M21297), SCaM4 (L01433), SCaM5 (L19359), Rsv1 (AY518517), Rps1-K-2 (AY963293), Rpg1-b (AY452685), AY518519, and AF175399. Plant SACPD sequences used for multiple alignment and phylogenetic analysis are listed in Supplemental Table 1. Sequence alignment was carried out using the Megalign program in the DNASTAR package and the neighbor-joining tree was constructed using the program PAUP* (Swofford 2000). Bootstrap numbers out of 100 replicates are given on the nodes. The tree was rooted with the algal SACPD sequence which was included as the outgroup.

\section{Glycerol treatment and SA measurements.}

Plants at the V1 growth stage were treated with glycerol solutions $(50,100,200,300$, and $400 \mathrm{mM})$ prepared in sterile water containing $0.04 \%$ Silwett L-77. Plants were sprayed every $24 \mathrm{~h}$ for 3 days and analyzed for various responses on the fourth day, unless noted otherwise. Control plants were sprayed with water containing $0.04 \%$ Silwett. SA and SAG were extracted and measured from leaf tissue (approximately $0.3 \mathrm{~g}$ of fresh weight) as described (Chandra-Shekara et al. 2004). Briefly, tissue was homogenized in $90 \%$ methanol and centrifuged, and the pellet was re-extracted using $100 \%$ methanol. The pooled supernatant was dried at $40^{\circ} \mathrm{C}$ under vacuum, resuspended in $5 \%$ trichloroacetic acid $(2.5 \mathrm{ml})$, and sonicated for $10 \mathrm{~min}$. Free and conjugated SA were separated in the organic and aqueous phases, respectively, via organic extraction with two volumes of ethylacetate-cyclopentane-isopropanol (50:50:1) and separated using high-performance liquid chromatography.

\section{FA analysis, trypan blue, and ROS staining.}

FAs were extracted from leaf, stem, and root tissues of plants at V1 growth stage, and flowers of plants at R1 stage, in methylated sulfuric acid at $80^{\circ} \mathrm{C}$, fractionated in hexane, and separated using gas chromatography as described earlier (Dahmer et al. 1989). Trypan blue staining of leaves from V1 plants grown in soil was performed as described (ChandraShekara et al. 2006). Briefly, leaf tissue was boiled in one volume of trypan blue solution (23\% phenol, $25 \%$ glycerol, $25 \%$ lactic acid, and trypan blue at $2.5 \mathrm{mg} / \mathrm{ml}$ ) and two volumes of $95 \%$ ethanol for $2 \mathrm{~min}$, followed by overnight destaining in chloral hydrate $(2.5 \mathrm{mg} / \mathrm{ml})$. Destained tissues were equilibrated in $80 \%$ glycerol and mounted for observation under a compound microscope. ROS formation in leaves from $\mathrm{V}$ or $\mathrm{D}$ (V3 stage) or W- or G-treated (V1 stage) plants was detected by visualizing fluorescence derived from vacuum infiltration of $20 \mu \mathrm{M} 2^{\prime}, 7^{\prime}$-dichlorodihydroflourescein diacetate.

\section{Pathogen inoculations.}

Pathogen inoculation of M, V, or D plants was carried out at the V3 growth stage. Pathogen inoculation of water or glyceroltreated plants was carried out at the V1 stage. All pathogeninoculated plants were grown in a growth chamber at $22^{\circ} \mathrm{C}$ with a 16-h photoperiod at $65 \%$ relative humidity. Pseudomonas syringae pv. glycinea and Phytophthora sojae infection assays were carried out on cv. Harosoy. Pseudomonas syringae was grown on King's B medium containing kanamycin $(50 \mu \mathrm{g} / \mathrm{ml})$ and rifampicin $(750 \mu \mathrm{g} / \mathrm{ml})$, as appropriate, at $28^{\circ} \mathrm{C}$. M, V, and D plants at V3 stage or W- or G-treated plants at V1 stage were infiltrated with bacterial suspensions at $1 \times 10^{5} \mathrm{CFU} / \mathrm{ml}$ in 10 $\mathrm{mM} \mathrm{MgCl}_{2}$ plus $0.04 \%$ Silwett L-77. Mock inoculations were carried out with $10 \mathrm{mM} \mathrm{MgCl}_{2}$ in $0.04 \%$ Silwett L-77. Bacterial growth was monitored by dilution plating of homogenated leaf discs excised using a $1-\mathrm{cm}$ cork borer at 0,3 , and 6 days postinoculation. At least five inoculated plants/treatment were sampled individually. Experiments were repeated three to four times. Phytophthora sojae race 2 strain P6497 was grown on lima bean agar at $25^{\circ} \mathrm{C}$ in the dark (Ayers et al. 1976). Phytophthora infection assays were carried out as described by Klarman and Gerdemann (1963). Briefly, soybean seedlings were inoculated by placing a small amount of mycelium in a vertical slit wound (approximately $1 \mathrm{~cm}$ in length) 2 to $3 \mathrm{~mm}$ below the cotyledons, and the wound was covered with parafilm. Mock inoculations were carried out with agar plugs without mycelia. Disease progression was monitored as the increase in lesion size over time. For W- or G-treated plants, disease progression was measured as the number of plants killed in response to $P$. sojae infection.

\section{ACKNOWLEDGMENTS}

This work was supported by grants from United States Department of Agriculture-NRI (2006-01854) to A. Kachroo and S. Ghabrial, NSF (MCB\#0421914) to P. Kachroo and A. Kachroo, and start-up funds from the Kentucky Agricultural Experiment Station to A. Kachroo. We thank A. Crume for help with managing the plant growth facility; L. Lapchyk and L. Xi for help with generating Arabidopsis transgenics; L. Orlav and T. Muse for help with DNA and FA extractions; J. Johnson for help with gas chromatography; A. Bogdanove, Iowa State University, for the Pseudomonas strains; and S. Abney, Purdue University, for the Phytophthora strains. This study is publication No. 08-12-033 of the Kentucky Agricultural Experiment Station. 


\section{LITERATURE CITED}

Akagi, H., Baba, T., Shimada, H., and Fujimura, T. 1995. Nucleotide sequence of a stearoyl-acyl carrier protein desaturase cDNA from developing seeds of rice. Plant Physiol. 108:845-846.

Ashfield, T., Bocian, A., Henk, A. D., Marek, L. F., Danesh, D., Penuela, S., Meksem, K., Lightfoot, D. A., Young, N. D., Shoemaker, R. C., and Innes, R. W. 2003. Genetic and physical localization of the soybean Rpg1- $b$ disease resistance gene reveals a complex locus containing several tightly linked families of NBS-LRR genes. Mol. Plant-Microbe Interact. 16:817-826

Ayers, A. R., Ebel, J., Finelli, F., Berger, N., and Albersheim, P. 1976. Host-pathogen interactions. IX. Quantitative assays of elicitor activity and characterization of the elicitor present in the extracellular medium of cultures of Phytophthora megasperma var. sojae. Plant Physiol. 57:751-759.

Bhattacharyya, M. K., Narayanan, N. N., Gao, H., Santra, D. K., Salimath, S. S., Kasuga, T., Liu, Y., Espinosa, B., Ellison, L., Marek, L., Shoemaker, R., Gijzen, M., and Buzzell, R. I. 2005. Identification of a large cluster of coiled coil-nucleotide binding site-leucine rich repeattype genes from the Rps1 region containing Phytophthora resistance genes in soybean. Theor. Appl. Genet. 111:75-86.

Browse, J., Warwick, N., Somerville, C. R., and Slack, C. R. 1986. Fluxes through the prokaryotic and eukaryotic pathways of lipid synthesis in the '16:3' plant Arabidopsis thaliana. Biochem. J. 235:25-31.

Byfield, G. E., Xue, H., and Upchurch, R. G. 2006. Two genes from soybean encoding soluble $\Delta 9$ stearoyl-ACP desaturases. Crop Sci. 46:840846.

Cahoon, E. B., Shanklin, J., and Ohlrogge, J. B. 1992. Expression of a coriander desaturase results in petroselinic acid production in transgenic tobacco. Proc. Natl. Acad. Sci. U.S.A. 89:11184-11188.

Cahoon, E. B., Dormann, P., and Ohlrogge, J. B. 1994. Petroselinic acid biosynthesis and production in transgenic plants. Prog. Lipid Res. $33: 155-163$

Cahoon, E. B., Coughlan, S. J., and Shanklin, J. 1997a. Characterization of a structurally and functionally diverged acyl-acyl carrier protein desaturase from milkweed seed. Plant Mol. Biol. 33:1105-1110.

Cahoon, E. B., Lindqvist, Y., Schneider, G., and Shanklin, J. 1997b. Redesign of soluble fatty acid desaturases from plants for altered substrate specificity and double bond position. Proc. Natl. Acad. Sci. U.S.A. 94:4872-4877.

Cahoon, E. B., Shah, S., Shanklin, J., and Browse, J. 1998. A determinant of substrate specificity predicted from the acyl-acyl carrier protein desaturase of developing cat's claw seed. Plant Physiol. 117:593-598.

Chandra-Shekara, A. C., Navarre, D., Kachroo, A., Kang, H. G., Klessig, D., and Kachroo, P. 2004. Signaling requirements and role of salicylic acid in HRT- and rrt-mediated resistance to Turnip crinkle virus in Arabidopsis. Plant J. 40, 647-59.

Chandra-Shekara, A. C., Gupte, M., Navarre, D., Raina, S., Raina, R., Klessig, D., and Kachroo, P. 2006. Light-dependent hypersensitive response and resistance signaling against Turnip crinkle virus in Arabidopsis. Plant J. 45:320-334.

Chandra-Shekara, A. C., Venugopal, S. C., Barman, S. R., Kachroo, A, and Kachroo, P. 2007. Plastidial fatty acid levels regulate resistance genedependent defense signaling in Arabidopsis. Proc. Natl. Acad. Sci. U.S.A. 104:7277-7282.

Cheesbrough, T. M. 1990. Decreased growth temperature increases soybean stearoyl-acyl carrier protein desaturase activity. Plant Physiol. 93:555-559.

Clough, S. J., and Bent, A. F. 1998. Floral dip: a simplified method for Agrobacterium-mediated transformation of Arabidopsis thaliana. Plant J. 16:735-743.

Dahmer, M. L., Fleming, P. D., Collins, G. B., and Hildebrand, D. F. 1989. A rapid screening for determining the lipid composition of soybean seeds. J. Am. Oil Chem. Soc. 66:534-538.

Emanuelsson, O., Nielsen, H., Brunak, S., and Heijne, G. V. 2000. Predicting subcellular localization of proteins based on their N-terminal amino acid sequence. J. Mol. Biol. 300:1005-1016.

Fox, S. R., Hill, L. M., Rawsthorne, S., and Hills, M. J. 2000. Inhibition of the glucose-6-phosphate transporter in oilseed rape (Brassica napus L.) plastids by acyl-CoA thioesters reduces fatty acid synthesis. Biochem. J. 352:525-532.

Gao, H., Narayanan, N. N., Ellison, L., and Bhattacharyya, M. K. 2005. Two classes of highly similar coiled coil-nucleotide binding-leucine rich repeat genes isolated from the Rpsl-k locus encode Phytophthora resistance in soybean. Mol. Plant-Microbe Interact. 18:1035-1045.

Gibson, K. J. 1993. Palmitoleate formation by soybean stearoyl-acyl carrier protein desaturase. Biochim. Biophys. Acta 1169:231-235.

Graham, M. A., Marek, L. F., and Shoemaker, R. C. 2002. Organization expression and evolution of a disease resistance gene cluster in soy- bean. Genetics 162:1961-1977.

Grillo, S., Consiglio, F., Costa, A., and Leone, A. 1998. Expression of genes for acyl-desaturases in response to temperature changes in potato cells. In: Proc. XV Eucarpia "Genetics and Breeding for Crop Quality and Resistance," Viterbo, Italy.

$\mathrm{Gu}, \mathrm{H}$., and Ghabrial, S. A. 2005. The Bean pod mottle virus proteinase cofactor and putative helicase are symptom severity determinants. Virology. 333:271-283.

Hayes, A. J., Jeong, S. C., Gore, M. A., Yu, Y. G., Buss, G. R., Tolin, S. A., and Saghai Maroof, M. A. 2004. Recombination within a nucleotidebinding-site/leucine-rich-repeat gene cluster produces new variants conditioning resistance to Soybean mosaic virus in soybeans. Genetics 166:493-503.

He, C.-Y., Zhang, J.-S., and Chen, S.-Y. 2002. A soybean gene encoding a proline-rich protein is regulated by salicylic acid, an endogenous circadian rhythm and by various stresses. Theor. Appl. Genet. 104:11251131.

Heinz, E., and Roughan, P. G. 1983. Similarities and differences in lipid metabolism of chloroplasts isolated from 18:3 and 16:3 plants. Plant Physiol. 72:273-279.

Heo, W. D., Lee, S. H., Kim, M. C., Kim, J. C., Chung, W. S., Chun, H. J., Lee, K. J., Park, C. Y., Park, H. C., Choi, J. Y., and Cho, M. J. 1999. Involvement of specific calmodulin isoforms in salicylic acid-independent activation of plant disease resistance responses. Proc. Natl. Acad. Sci. U.S.A. 96:766-771.

Jain, R. K., Thompson, R. G, Taylor, D. C., McKenzie, S. L., McHughen, A., Rowland, G. G., and Coffey, M. 1999. Isolation and characterization of two promoters from linseed for genetic engineering. Crop Sci. 39:1696-1701.

Kachroo, P., Shanklin, J., Shah, J., Whittle, E. J., and Klessig, D. F. 2001. A fatty acid desaturase modulates the activation of defense signaling pathways in plants. Proc. Natl. Acad. Sci. U.S.A. 98:9448-9453.

Kachroo, P., Kachroo, A., Lapchyk, L., Hildebrand, D., and Klessig, D. 2003a. Restoration of defective cross-talk in ssi2 mutants: role of salicylic acid, jasmonic acid, and fatty acids in ssi2-mediated signaling. Mol. Plant-Microbe Interact. 11:1022-1029.

Kachroo, A., Lapchyk, L., Fukushigae, H., Hildebrand, D., Klessig, D., and Kachroo, P. 2003b. Plastidal fatty acid signaling modulates salicylic acid- and jasmonic acid-mediated pathways in the Arabidopsis ssi 2 mutant. Plant Cell 15:2952-2965.

Kachroo, A., Venugopal, S. C., Lapchyk, L., Falcone, D., Hildebrand, D., and Kachroo, P. 2004. Oleic acid levels regulated by glycerolipid metabolism modulate defense gene expression in Arabidopsis. Proc. Natl. Acad. Sci. U.S.A. 101:5152-5157.

Kachroo, P., Venugopal, S. C., Navarre, D. A., Lapchyk, L., and Kachroo, A. 2005. Role of salicylic acid and fatty acid desaturation pathways in ssi2-mediated signaling. Plant Physiol. 139:1717-1735.

Kachroo, A., Shanklin, J., Whittle, E., Lapchyk, L., Hildebrand, D., and Kachroo, P. 2007. The Arabidopsis stearoyl-acyl carrier protein-desaturase family and the contribution of leaf isoforms to oleic acid synthesis. Plant Mol. Biol. 63:257-271.

Karpichev, I. V., and Small, G. M. 1998. Global regulatory functions of Oaf1p and Pip2p (Oaf2p), transcription factors that regulate genes encoding peroxisomal proteins in Saccharomyces cerevisiae. Mol. Cell. Biol. 18:6560-6570.

Klarman, W. L., and Gerdemann, J. W. 1963. Induced susceptibility in soybean plants genetically resistant to Phytophthora sojae. Phytopathol Notes 53:863-864.

Lindqvist, Y., Huang, W., Schneider, G., and Shanklin, J. 1996. Crystal structure of delta9 stearoyl-acyl carrier protein-desaturase from castor seed and its relationship to other di-iron proteins. EMBO (Eur. Mol. Biol. Organ.) J. 15:4081-4092.

Mazarei, M., Elling, A. A, Maier, T. R., Puthoff, D. P., and Baum, T. J. 2007. GmEREBP1 is a transcription factor activating defense genes in soybean and Arabidopsis. Mol. Plant-Microbe Interact. 20:107-119.

Menendez, J. A., and Lupu, R. 2006. Mediterranean dietary traditions for the molecular treatment of human cancer: anti-oncogenic actions of the main olive oil's monounsaturated fatty acid oleic acid (18:1n-9). Curr. Pharmacol. Biotechnol. 7:495-502.

Nandi, A., Krothapalli, K., Buseman, C. M., Li, M., Welti, R., Enyedi, A., and Shah, J. 2003. Arabidopsis sfd mutants affect plastidic lipid composition and suppress dwarfing, cell death, and the enhanced disease resistance phenotypes resulting from the deficiency of a fatty acid desaturase. Plant Cell. 15:2383-2398.

Nishida, I., Beppu, T., Matsuo, T., and Murata, N. (1992) Nucleotide sequence of a cDNA clone encoding a precursor to stearoyl-(acyl-carrierprotein) desaturase from spinach, Spinacia oleracea. Plant Mol. Biol. 19:711-713.

Ntambi, J. M., and Miyazaki, M. 2003. Recent insights into stearoyl-CoAdesaturase-1. Curr. Opin. Lipidol. 14:255-261. 
Park, C. Y., Heo, W. D., Yoo, J. H., Lee, J. H., Kim, M. C., Chun, H. J. Moon, B. C., Kim, I. H., Park, H. C., Choi, M. S., Ok, H. M., Cheong, M. S., Lee, S. M., Kim, H. S., Lee, K. H., Lim, C. O., Chung, W. S., and Cho, M. J. 2004. Pathogenesis-related gene expression by specific calmodulin isoforms is dependent on NIM1, a key regulator of systemic acquired resistance. Mol. Cells 18:207-213.

Pedersen, P. 2004. Soybean growth and development stages. Publication PM1945. Iowa State University Extension Service, Des Moines, IA, U.S.A.

Pegadaraju, V., Knepper, C., Reese, J., and Shah, J. 2005. Premature leaf senescence modulated by the Arabidopsis PHYTOALEXIN DEFICIENT4 gene is associated with defense against the phloem-feeding green peach aphid. Plant Physiol. 139:1927-1934.

Restrepo, M. A., Freed, D. D., and Carrington, J. C. 1990. Nuclear transport of plant potyvirus proteins. Plant Cell 2:987-998.

Rodríguez-Rodríguez, R. A., Tabernero, A., Velasco, A., Lavado, E. M., and Medina, J. M. 2004. The neurotrophic effect of oleic acid includes dendritic differentiation and the expression of the neuronal basic helix-loop-helix transcription factor NeuroD2. J. Neurochem. 88:1041-1051.

Rottensteiner, H., Hartig, A., Hamilton, B., Ruis, H., Erdmann, R., and Gurvitz, A. 2003. Saccharomyces cerevisiae Pip2p-Oaf1p regulates PEX25 transcription through an adeninie-less ORE. Eur. J. Biochem. 270:2013-2022

Roughan, P. G. 1987. On the control of fatty acid compositions of plant glycerolipids. Pages 247-255 in: The Metabolism, Structure, and Function of Plant Lipids. P. K. Stumpf, J. B. Mudd, and W. D. Nes, eds. Plenum, New York.

Roughan, P. G., and Slack, C. R. 1984. Glycerolipid synthesis in leaves. Trends Biochem. Sci. 9:383-386.

Schultz, D. J., Cahoon, E. B., Shanklin, J., Craig, R., Cox-Foster, D. L., Mumma, R. O., and Medford, J. I. 1996. Expression of a delta 9 14:0acyl carrier protein fatty acid desaturase gene is necessary for the production of omega 5 anacardic acids found in pest-resistant geranium (Pelargonium xhortorum). Proc. Natl. Acad. Sci. U.S.A. 93:87718775.

Shah, J., Kachroo, P., Nandi, A., and Klessig, D. F. 2001. A recessive mutation in the Arabidopsis SSI2 gene confers SA- and NPR1-independent expression of $P R$ genes and resistance against bacterial and oomycete pathogens. Plant J. 25:563-574.

Shanklin, J., and Somerville, C. 1991. Stearoyl-acyl-carrier-protein protein desaturase from higher plants is structurally unrelated to the animal and fungal homologs. Proc. Natl. Acad. Sci. U.S.A. 88:2510-2514.

Slocombe, S. P., Cummins, I., Jarvis, R. P., and Murphy, D. J. 1992. Nucleotide sequence and temporal regulation of a seed-specific Brassica napus cDNA encoding a stearoyl-acyl carrier protein (ACP) desaturase. Plant Mol. Biol. 20:151-155.

Svanborg, C., Agerstam, H., Aronson, A., Bjerkvig, R., Düringer, C., Fischer, W., Gustafsson, L., Hallgren, O., Leijonhuvud, I., Linse, S., Mossberg, A. K., Nilsson, H., Pettersson, J., and Svensson, M. 2003. HAMLET kills tumor cells by an apoptosis-like mechanism-cellular, molecular, and therapeutic aspects. Adv. Cancer Res. 88:1-29.

Swofford, D. L. 2000. PAUP: Phylogenetic Analysis Using Parsimony and Other Methods (software). Sinaur Associates, Sunderland, MA, U.S.A.

Taylor, M. A., Smith, S. B., Davies, H. V., and Burch, L. R. 1992. The primary structure of a cDNA clone of the stearoyl-acyl carrier protein desaturase gene from potato (Solanum tuberosum L.). Plant Physiol. 100:533-534

Thompson, G. A., Scherer, D. E., Foxall-Van, A. S., Kenny, J. W., Young, H. L., Shintani, D. K., Kridl, J. C., and Knauf, V. C. 1991. Primary structures of the precursor and mature forms of stearoyl-acyl carrier protein desaturase from safflower embryos and requirement of ferredoxin for enzyme activity. Proc. Natl. Acad. Sci. U.S.A. 88:2578-2582.

Vannini, C., Locatelli, F., Bracale, M., Magnani, E., Marsoni, M., Osnato, M., Mattana, M., Baldoni, E., and Coraggio, I. 2004. Overexpression of the rice Osmyb4 gene increases chilling and freezing tolerance of Arabidopsis thaliana plants. Plant J. 37:115-127.

Wade, N. L., and Bishop, D. G. 1978.) Changes in lipid composition of ripening banana fruits and evidence for an associated increase in cell membrane permeability. Biochim. Biophys. Acta 529:454-460.

Wang, C., and Wang, X. 2001. A novel phospholipase D of Arabidopsis that is activated by oleic acid and associated with the plasma membrane. Plant Physiol. 127:1102-1112.

Yu, Y. G., Buss, G. R., and Maroof, M. A. 1996. Isolation of a superfamily of candidate disease-resistance genes in soybean based on a conserved nucleotide-binding site. Proc. Natl. Acad. Sci. U.S.A. 93:11751-11756.

Zhang, C., and Ghabrial, S. A. 2006. Development of bean pod mottle virus-based vectors for stable protein expression and sequence-specific virus-induced gene silencing in soybean. Virology 344:401-411.

Zheng, Y., Prouty, S. M., Harmon, A., Sundberg, J. P., Stenn, K. S., and Parimoo, S. 2001. Scd3-a novel gene of the stearoyl-CoA-desaturase family with restricted expression in skin. Genomics 71:182-191.

\section{AUTHOR-RECOMMENDED INTERNET RESOURCES}

SoyBase G. max and G. sojae webpage: delbruck.agron.iastate.edu/blast/GlycineSequences.html

Dana-Farber Cancer Institute: compbio.dfci.harvard.edu/tgi/cgibin/tgi/Blast/index.cgi 